Archive for

Organic Chemistry

Arkivoc 2019, part v, 0-0

\title{
Fluorine substituted non-symmetric phenazines: a new synthetic protocol from polyfluorinated azobenzenes
}

\author{
Luca Vaghi,* Mattia Coletta, Paolo Coghi, Ivan Andreosso, Luca Beverina, Riccardo Ruffo, and Antonio \\ Papagni
}

Department of Materials Science, University of Milano-Bicocca, via R. Cozzi 55, 20125 Milano, Italy

Email: luca.vaghi@unimib.it

Received 03-27-2019

Accepted 06-04-2019

Published on line $07-03-2019$

\section{Abstract}

A high ortho regioselectivity in nucleophilic aromatic substitution in low polar solvents is reported in the reaction of polyfluorinated azobenzenes with anilines. 0 -Anilino substituted derivatives could be easily transformed into non-symmetric phenazines by acid catalyzed electrocyclization. Phenazines are interesting compounds for their important properties as bioactive molecules. In addition, these fluorinated phenazines manifest interesting spectroscopic and electronic properties that make them candidates for $\mathrm{n}$-type organic semiconductor. Furthermore, the prepared phenazines show reversible reduction with the LUMO and HOMO energy level controlled by the electronic nature of the substituent on the non-fluorinated ring of the system.
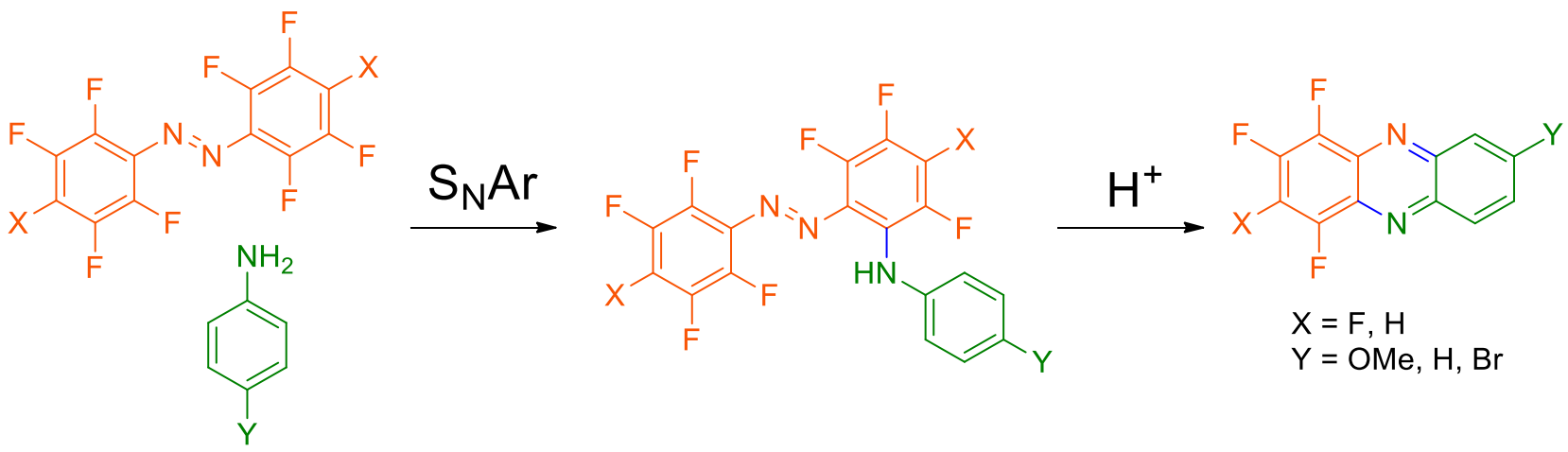

Keywords: Polyfluorinated compounds, azobenzenes, phenazines, aromatic nucleophilic substitution, nitrogen-containing heterocycles 


\section{Introduction}

Phenazines, known since the beginning of 19th century, represent an important class of heterocycles showing a great potential as bioactive molecules and as organic-based semiconducting materials. As an example, phenazines, isolated from Pseudomonas, Streptomyces and from soil or marine organisms manifest important biological properties including antibiotic, antitumor, antimalaria and antiparasitic activities ${ }^{1-3}$ and recently, it is also reported their biofilm eradication properties in the treatment of antibiotic resistant bacteria. ${ }^{4}$ In addition, fluorinated phenazines have received particular attention since they present interesting HOMO and LUMO energy levels respect to the hydrogenated counterpart ${ }^{5,6}$ and have been proposed as $n$-type semiconductors potentially exploitable for developing new organic light emitting diode (OLED) and organic field effect transistor (OFET) devices. ${ }^{7,8}$ Furthermore, fully fluorinated phenazine has been proposed as system for photochemical oxidation of water with a potential application in light induced water splitting processes. ${ }^{9}$

Despite these peculiar properties, a limited number of phenazines are known or commercially available and this is basically due to the lack of general protocols for their synthesis, limited library of starting materials, harsh experimental conditions and low yields. The reported synthetic strategies can be divided meanly in two categories: (1) strategies for symmetrical substituted phenazines and (2) strategies for unsymmetrical substituted phenazine (Scheme 1). Within the protocols of the first type deserve to be mentioned: the dimerization of nitroso-arenes by Bamberger-Ham reaction, ${ }^{10}$ the dimerization of anilines via $\mathrm{Pd}-\mathrm{Ag} \mathrm{C}-\mathrm{H}$ activation ${ }^{11}$ and the homocoupling of 2-iodoanilines catalysed by sulfonato- $\mathrm{Cu}\left(\right.$ salen) complex. ${ }^{12}$ Within those of second type, the reported synthetic approaches are: the historical Wohl-Aue by condensation of nitro aromatics and anilines, ${ }^{13,14}$ the reductive cyclization of 2-nitrodiphenylamines by sodium borohydride in ethanolic sodium ethoxide solution, ${ }^{15}$ the combination of 2-bromo-anilines with 2-bromo-nitrobenzenes via sequential Buchwald-reduction-Buchwald, ${ }^{16}$ the reaction of 2-bromo-nitrobenzenes with anilines via Buchwald-Hartwig/reductive cyclization, ${ }^{17}$ the condensation between a quinone and orthophenylenediamine ${ }^{2,18}$ and the Rh-catalysed ortho-amination of azobenzenes with aryl azides. ${ }^{19}$

Symmetric phenazines

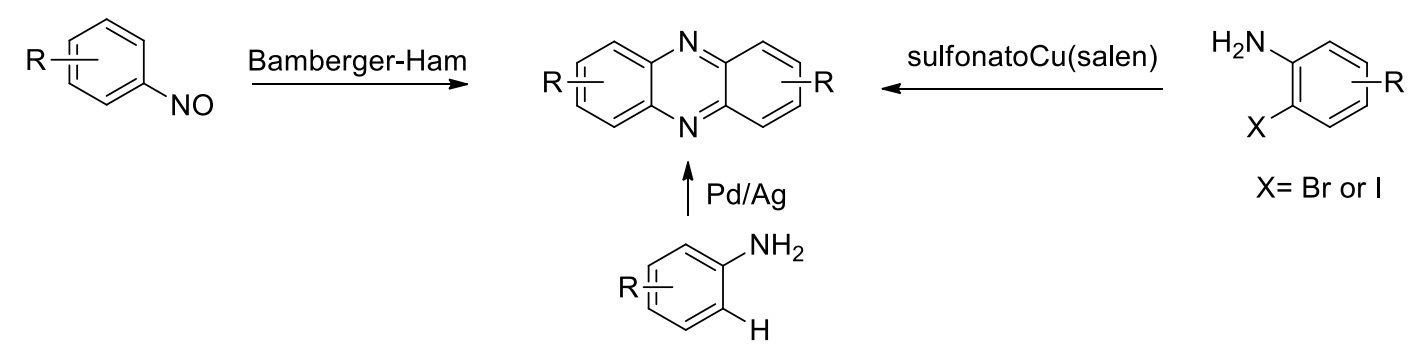

Unsymmetric phenazines

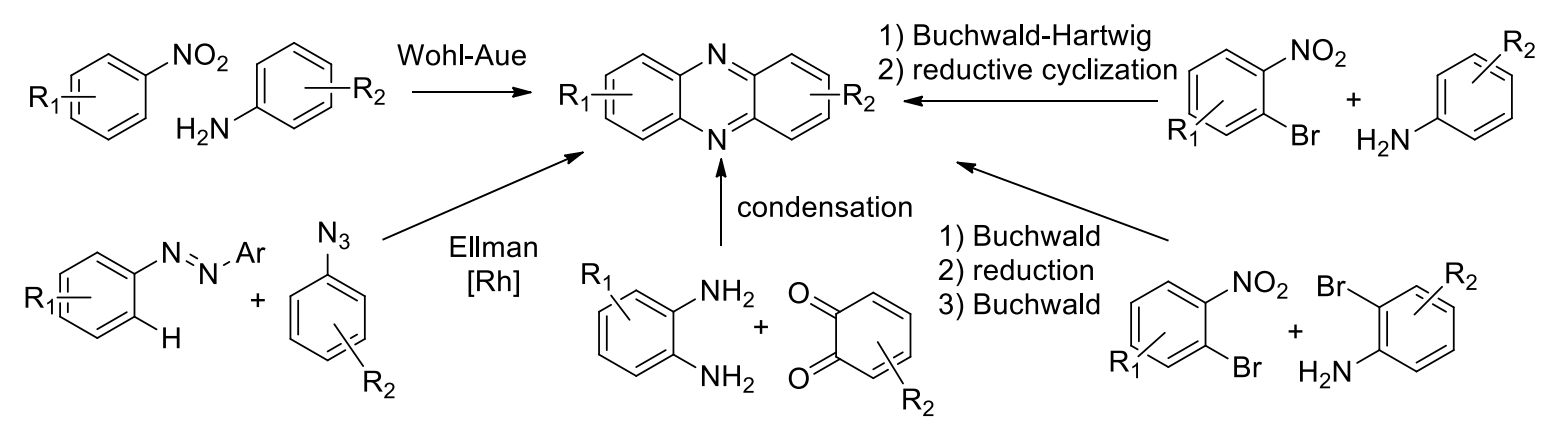

Scheme 1. Synthetic strategies to symmetric and non-symmetric substituted phenazines. 
In the Rh-catalyzed phenazine synthesis from azobenzenes and azides developed by Ellman, ${ }^{19}$ an orthoanilino substituted azobenzene is proposed as key intermediate in the catalytic cycle. To obtain reasonable chemical yield in the corresponding phenazines the use glacial acetic acid as solvent is a crucial factor. Indeed, acetic acid facilitates the [3,3]-sigmatropic rearrangement by favoring the ortho-quinoid hydrazinic form (in prototropic equilibrium with the ortho-anilino substituted azobenzene) as well as the ejection and sequestration of the aniline during the aromatization process. The latter aspect is important since the aniline can inhibit the catalyst. The use of non-symmetric azo-derivatives is suggested to drive the ortho-metalation only on the less hindered aromatic ring bound to the azo function.

Symmetric polyfluorophenazines are obtained as by-products in the chemical ${ }^{20}$ and electrochemical ${ }^{21}$ oxidation of polyfluorinated anilines to the corresponding azobenzene, while very limited reports describe protocols for the preparation of non-symmetric polyfluorinated phenazines. Indeed, 2,3-difluorophenazine derivatives are prepared by reacting the corresponding 3,4-difluoro-phenylendiamine with 2,5-dihydroxy-1,4benzoquinone, ${ }^{22}$ 1,2,3,4-tetrafluorophenazines are reported to be isolated as by-product from the thermal decomposition of aryl azides in the presence of pentafluoroaniline ${ }^{23}$ and by heating the respective quinoxaline derivative of 7,8-dioxo-3-methyl-3-phenyl-1,4,5,6-tetrafluorobicyclo[2.2.2] oct-5-ene (Scheme 2). ${ }^{24}$

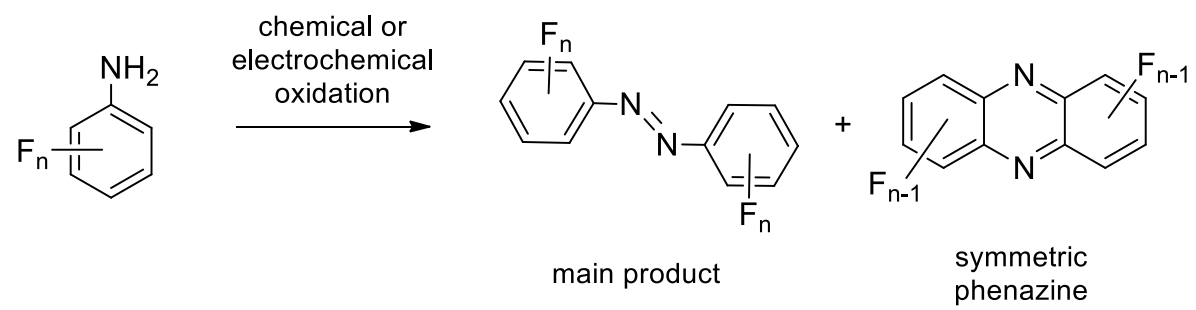

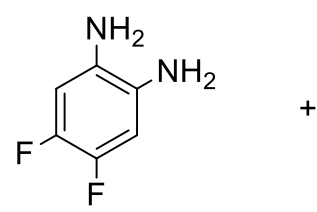

3,4-difluorophenylendiamine<smiles>O=C1C=C(O)C(=O)C=C1O</smiles>

2,5-dihydroxy1,4-benzoquinone<smiles>Oc1cc2nc3cc(F)c(F)cc3nc2cc1O</smiles>

2,3-difluoro-

7,8-hydroxyphenazine

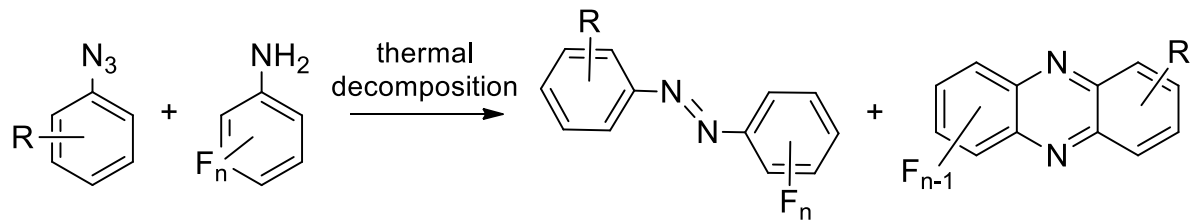

main product

non symmetric phenazine

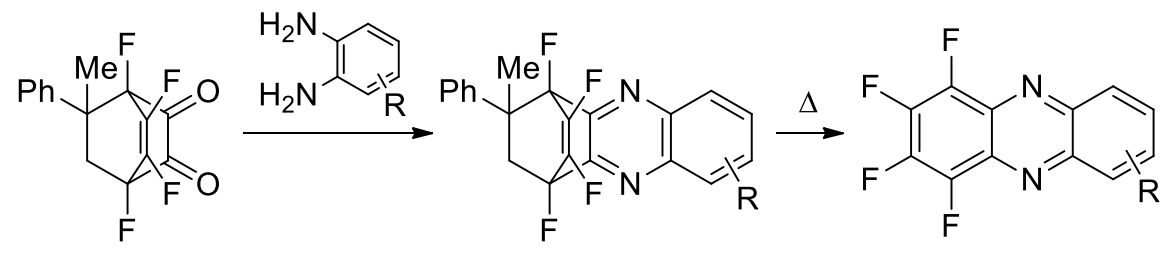

7,8-dioxo-3-methyl-

3-phenyl-1,4,5,6-

tetrafluorobicyclo[2.2.2]oct-5-ene

Scheme 2. Synthetic pathways to polyfluorophenazines. 


\section{Results and Discussion}

Herein we report a new protocol for the synthesis of 1,2,3,4-tetrafluoro and 1,3,4-triflurophenazines starting from polyfluoroazobenzenes and anilines. The synthetic strategy is based on our methodology developed in the past for synthesizing 1,2,3,4-tetrafluoroacridines. ${ }^{25}$ In this methodology, the decafluorobenzophenone undergoes ortho nucleophilic aromatic substitution $\left(S_{N} A r\right)$ by reacting with anilines, with the ortho/para regiochemistry controlled by the solvent basicity (expressed by its Donor Number, $\mathrm{DN}^{26}$ ). Indeed, thanks to the hydrogen bonding between the $\mathrm{N}-\mathrm{H}$ of the aniline and the lone pair of the carbonyl group, a high ortho/para regioselectivity is observed solvents of low donicity. The resulting intermediate is subsequently treated under strong acidic conditions to afford the target acridines via $6 \pi$ electrocyclization. Acridines and phenazines are structurally related, thus we supposed that a similar protocol could be apply for the preparation of fluorinated phenazines (Scheme 3). We identify polyfluoroazobenzenes as ideal starting material for this strategy, obviously high level of fluorination is required to achieve the $S_{N} A r$ and at least one fluorine must be present in the ortho position. In similar experimental conditions (low DN solvent), a hydrogen bonding is also expected between the lone pair of the nitrogen of the azo group and the $\mathrm{N}-\mathrm{H}$ hydrogen of aromatic amines.

Previous work:
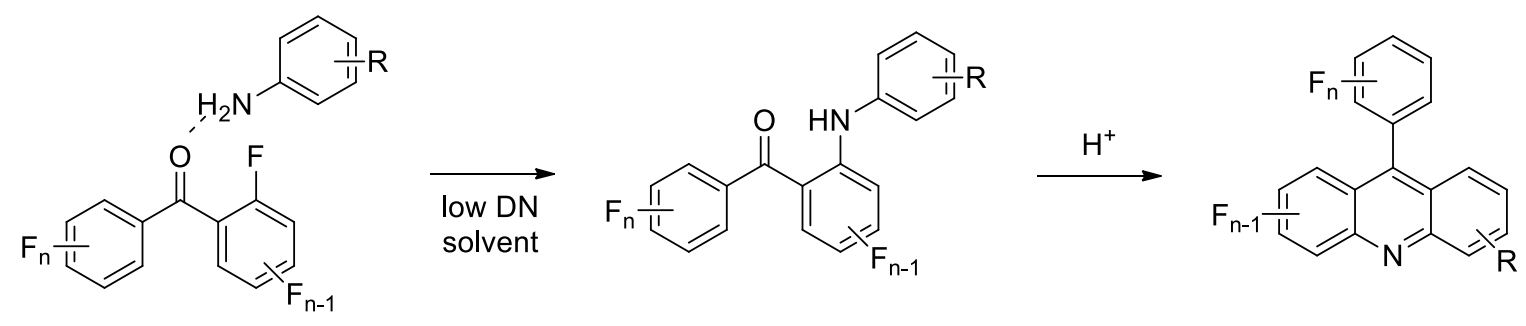

Current work:
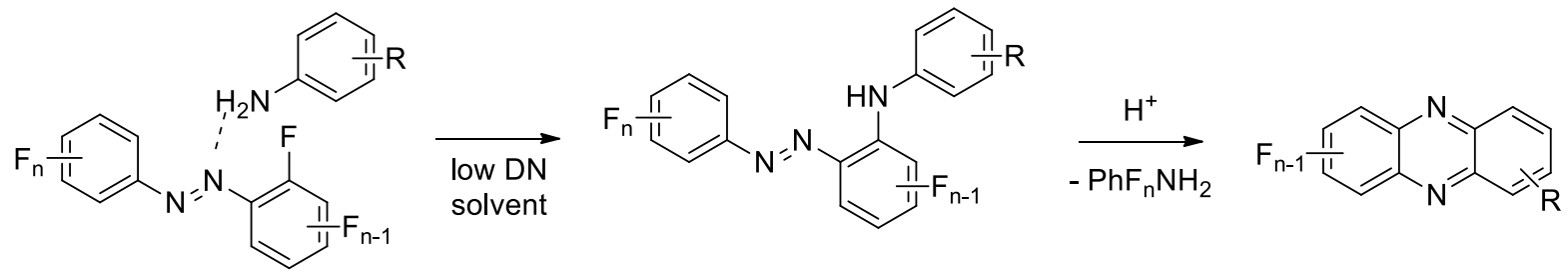

Scheme 3. Phenazines versus acridines synthetic strategies.

Compared to polyfluorobenzophenone it is expected that polyfluoroazobenzene could exploit a similar reactivity towards nucleophiles since, thanks to the conjugation capability of azo group, both the two polyfluoroaromatic rings should show a more electron-poor character. This is also supported by the known reactivity of decafluoroazobenzene towards oxygen- and nitrogen-nucleophiles. ${ }^{27}$ In our strategy the preparation ortho-anilino substituted intermediates could be carried out by fluorine $\mathrm{S}_{N} A r$ with anilines on the suitable polyfluorinated azobenzene, avoiding to the use of expensive catalysts and aromatic azides required in the Ellman protocol. ${ }^{19}$ This latter, as additional drawback, requires azobenzenes bearing at least a hydrogen ortho to the azo function.

The synthesis of symmetrical azobenzenes has been reported via the oxidation of primary aromatic amines with different oxidants, ${ }^{28}$ but in the case of highly fluorinated anilines the oxidation of amino group requires an excess of strong oxidants such $\mathrm{Pb}(\mathrm{OAc}){ }_{4}{ }^{20}$ to afford reproducible and satisfactory results when gram quantity of products are needed. Recently, we develop a mechanochemical methodology to afford 
polyfluoro symmetric azobenzenes from the corresponding anilines. ${ }^{29}$ When applicable, the mechano-chemistry represents the optimal experimental condition, since solvents are avoided and the reagents are at their maximum concentration, thereby resulting in shorter reaction times and simple work up procedures. By this technique, starting from pentafluoroaniline $\mathbf{1 a}$ and tetrafluoroaniline $\mathbf{1 b}$, gram scale of decafluoroazobenzene $\mathbf{2} \mathbf{a}$ and octafluoroazobenzene $\mathbf{2 b}$, respectively, were easily prepared (Scheme 4).
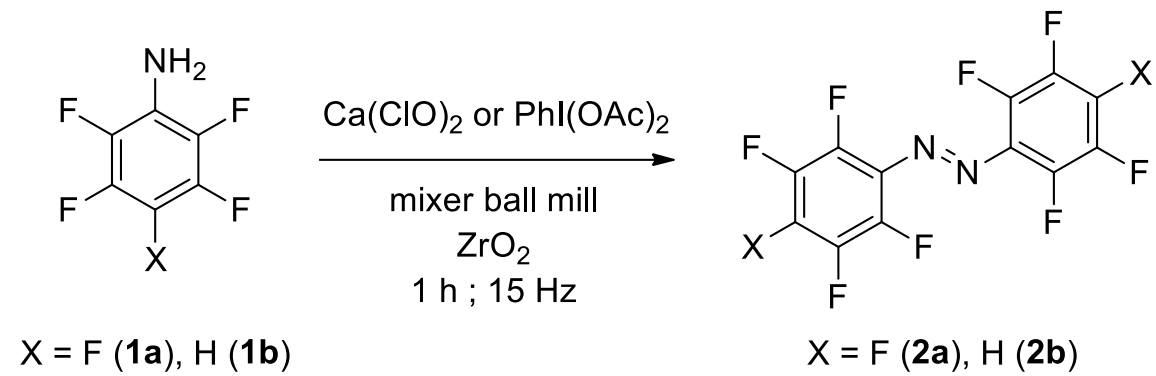

$X=F(2 \mathbf{a}), H(2 \mathbf{b})$

Scheme 4. Mechanochemical oxidation of fluorinated anilines.

$\mathbf{2 a}$ and $\mathbf{2} \mathbf{b}$ were then subjected to the $S_{N} A r$ reaction with three aromatic amines with decreasing electron richness, i.e. 4-methoxyaniline $\mathbf{3 a}$, aniline $\mathbf{3 b}$ and 4 -bromoaniline $\mathbf{3 c}$ (Scheme 5). In the case of $\mathbf{2 a}$, to drive the reaction in favor to the ortho-substitution products, it is mandatory to operate in low polar solvents (i.e. $\mathrm{DN}=$ $0)$, otherwise the para position will be the most reactive. Conversely, the reaction with $\mathbf{2} \mathbf{b}$ can be carried out in solvent with higher DN since para position is no more reactive by the presence of hydrogens.<smiles>[X]c1c(F)c(F)c(N=Nc2c(F)c(F)c([X])c(F)c2F)c(F)c1F</smiles>
$X=F(2 a), H(2 b)$<smiles>[Y]c1ccc(N)cc1</smiles>

$\mathrm{Y}=\mathrm{OMe}(\mathbf{3 a})$

$\mathrm{H}(3 \mathbf{b})$

$\mathrm{Br}(3 \mathrm{c})$<smiles>[X]c1ccc(Nc2c(F)c([X])c(F)c(F)c2N=Nc2c(F)c(F)c([X])c(F)c2F)cc1</smiles>

4aa $X=F, Y=O M e(57 \%)$

4ab $X=F, Y=H(54 \%)$

4ac $X=F, Y=B r(61 \%)$

4ba $X=H, Y=O M e(68 \%)$

4bb $X=H, Y=H(55 \%)$

4bc $X=H, Y=B r(63 \%)$

Scheme 5. Regioselective ortho-SNAr of $\mathbf{2 a}$ and $\mathbf{2} \mathbf{b}$ with anilines.

Thus, 1,2-dichloroethane (DCE) and decalin ( $D N=0)$ were chosen as solvent to test the $\mathrm{S}_{N} A r$ reaction on $\mathbf{2 a}$, 2 equiv of aniline 3a were used, 1 equiv serves as HF scavenger (Table 1, Entries 1 and 2), a sacrificial base such as triethylamine could interfere in the hydrogen bonding system. Under these conditions, we were able to isolate $43 \%$ of 4 aa in refluxing DCE and $15 \%$ in decalin at $170{ }^{\circ} \mathrm{C}$. The higher boiling point of decalin allowed the reaction to be complete in $2 \mathrm{~h}$ respect to $6 \mathrm{~h}$ for DCE. Polysubstitution by-products were heavily present, especially when the reaction was performed in decalin, indicating that at the temperature of $170{ }^{\circ} \mathrm{C}$ in such low polar environment the HF formed moves away on gaseous form. Then, focusing at decalin, we lowered the $\mathbf{2 a : 3 a}$ ratio to $1: 1.5$ (Table 1, Entry 3), increased yield (35\%) and less polysubstitution by-products were 
observed. We finally used 1:1.1 2a:3a ratio with a slow flow of nitrogen and an aqueous $\mathrm{K}_{2} \mathrm{CO}_{3}$ trap at the end to capture the HF (Table 1, Entry 4), with this setup a satisfactory $57 \%$ isolated yield was achieved. The procedure was repeated with $\mathbf{3 b}$ and $3 \mathrm{c}$ (Table 1, Entries 5 and 6) affording 54\% of 4ab and 61\% of 4ac, respectively. Finally, we performed the ortho-substitution on $\mathbf{2 b}$. The absence of selectivity issues allowed the use of standard conditions for $\mathrm{S}_{N} A r$, namely dimethyl sulfoxide (DMSO) ( $D N=29.8$ ) as solvent, $\mathrm{Et}_{3} \mathrm{~N}$ as sacrificial base at room temperature, affording the desired $\mathbf{4 b a}, \mathbf{4 b b}$ and $\mathbf{4 b c}$ in $68 \%, 55 \%$ and $63 \%$ yield, respectively (Table 1, Entries 7, 8 and 9).

Table 1. Outputs of the nucleophilic aromatic substitution of $\mathbf{2 a}$ and $\mathbf{2} \mathbf{b}$ with anilines

\begin{tabular}{|c|c|c|c|c|c|c|c|}
\hline Entry & Substrate & Aniline & Ratio 2:3 & Solvent & $\mathrm{T}^{\circ} \mathrm{C}$ & Time $\mathrm{h}$ & Yield \% \\
\hline 1 & $2 a$ & $3 a$ & $1: 2$ & DCE & 84 & 6 & 43 \\
\hline 2 & $2 a$ & $3 a$ & $1: 2$ & decalin & 170 & 2 & 15 \\
\hline 3 & $2 a$ & $3 a$ & 1:1.5 & decalin & 170 & 2 & 35 \\
\hline $4^{a}$ & $2 a$ & $3 a$ & 1:1.1 & decalin & 170 & 2 & 57 \\
\hline $5^{a}$ & $2 a$ & $3 b$ & 1:1.1 & decalin & 170 & 4 & 54 \\
\hline $6^{a}$ & $2 a$ & $3 c$ & 1:1.1 & decalin & 170 & 4 & 61 \\
\hline $7^{b}$ & $2 b$ & $3 a$ & 1:1.1 & DMSO & 20 & 3 & 68 \\
\hline $8^{b}$ & $2 b$ & $3 b$ & 1:1.1 & DMSO & 20 & 5 & 55 \\
\hline $9^{b}$ & $2 b$ & $3 c$ & $1: 1.1$ & DMSO & 20 & 5 & 63 \\
\hline
\end{tabular}

${ }^{a} \mathrm{~N}_{2}$ flow and aqueous $\mathrm{K}_{2} \mathrm{CO}_{3}$ trap. ${ }^{\mathrm{b}} \mathrm{Et}_{3} \mathrm{~N}$ (1 equiv).

The ortho-substituted products $\mathbf{4}$ have been transformed into the corresponding phenazines $\mathbf{5}$ by acid-catalyzed electrocyclic reaction (Scheme 6). As previously described for the synthesis of acridines, 25,30 trifluoroacetic acid (TFA) has been selected to be used both as catalyst and as reaction solvent. The electrocyclic reactions occur in very mild condition by simple stirring at room temperature overnight affording the desired products in satisfactory yields ranging from $50 \%$ to $74 \%$.
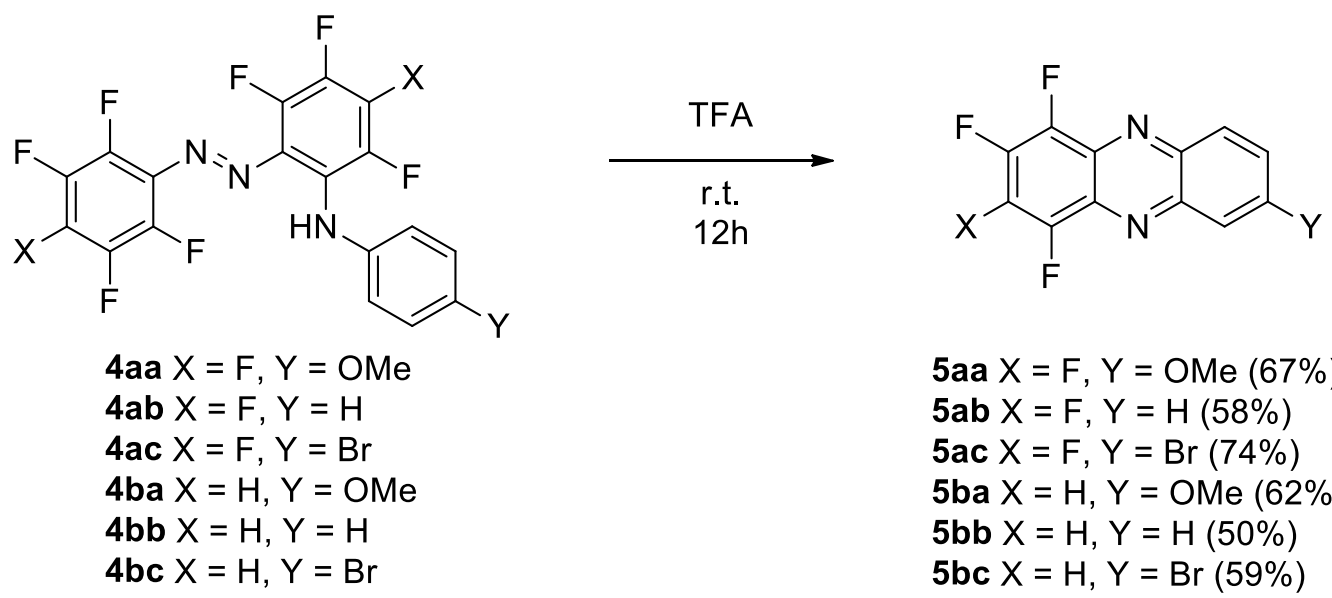

$$
\begin{aligned}
& \text { 5aa } X=F, Y=O M e(67 \%) \\
& \text { 5ab } X=F, Y=H(58 \%) \\
& \text { 5ac } X=F, Y=\operatorname{Br}(74 \%) \\
& \text { 5ba } X=H, Y=O M e(62 \%) \\
& \text { 5bb } X=H, Y=H(50 \%) \\
& \text { 5bc } X=H, Y=\operatorname{Br}(59 \%)
\end{aligned}
$$

Scheme 6. Acid catalyzed electrocyclization-aromatization of derivatives 4.

In analogy to ortho-anilino substituted nonaflurorobenzophenones, ${ }^{25}$ a similar mechanism for the transformation of derivatives 4 into 5 can be proposed (Scheme 7). Thus, it is reasonable that the cyclization 
proceeds via $6 \pi$-electrocyclization, involving the hydrazone form of the azo group favored by a prototropic process in the strong acid media, to give the target phenazine with ejection of a molecule of fluoroaniline. A similar mechanism has been proposed by Ellman, ${ }^{19}$ where the cyclization is driven by the acidic conditions of the reaction media.

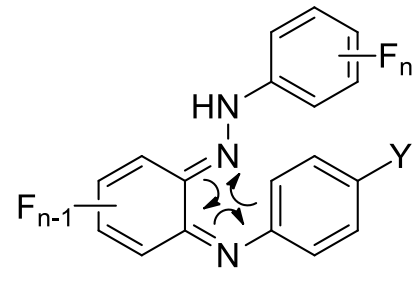

4

4

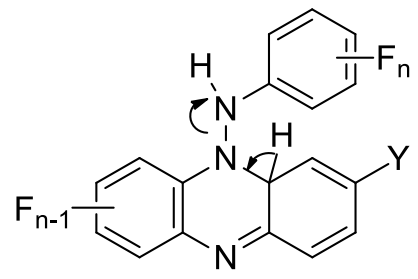

$$
\text { (n) }
$$

Scheme 7. Mechanism of the acid-catalyzed electrocyclization-aromatization.

The tetrafluoro phenazines 5aa, 5ab and 5ac were spectroscopically and electrochemically characterized (Table 2). Absorption maxima are at $360 \mathrm{~nm}$ for $5 a a, 370 \mathrm{~nm}$ for $5 \mathbf{a b}$ and 374 for 5 ac. The emission is in the visible region with an energy modulated by the electron-donating nature of the substituent $Y$, ranging from $435 \mathrm{~nm}$ to $484 \mathrm{~nm}$ with Stoke shifts up to $120 \mathrm{~nm}$. The emission is also observed in the solid state. The replacement of hydrogens with electronegative fluorine atoms strongly influences the electrochemical properties and HOMO-LUMO energy level. Indeed, a significant lowering of both HOMO and LUMO energies has been observed in phenazines 5 with differences greater than $0.3 \mathrm{eV}$ when compared to the non-fluorinated phenazine (LUMO $=-3.4 \mathrm{eV}) .{ }^{31}$ The fluorination also makes phenazines particularly stable to oxidation with HOMO orbital energy almost in all cases below $-6 \mathrm{eV}$. As expected, the presence of electrondonating groups has a greater effect on the energy of HOMO orbitals than on the corresponding LUMOs. The reduction potential is in line with the effect exerted by substituents. Thanks to their HOMO and LUMO energy levels and their low band gaps (<3 eV) Phenazines 5aa, 5ab and 5ac possess electronic properties that make them very attractive for applications in photovoltaic devices. In addition, the energy level of the HOMO is lower than the air oxidation threshold $(-5.2 \mathrm{eV})$, and this is important since a significant stability against oxidative degradation is expected.

Table 2. Spectroscopic and electrochemical characteristics of phenazines 5aa, 5ab and 5ac

\begin{tabular}{lllllll}
\hline Phenazine & $A \lambda \max (\mathrm{nm})$ & $\mathrm{E} \lambda \max (\mathrm{nm})$ & $\begin{array}{l}\mathrm{E}_{0} \text { red }(V) \text { vs. } \\
\mathrm{Fc}^{+} / \mathrm{Fc}\end{array}$ & $\begin{array}{l}\text { Optical band } \\
\text { gap (eV) }\end{array}$ & HOMO $(\mathrm{eV})^{\mathrm{a}}$ & $\mathrm{LUMO}^{(\mathrm{eV})^{\mathrm{b}}}$ \\
\hline 5aa & 360,404 & 480 & -1.44 & 2.58 & -6.33 & -3.75 \\
5ab & 370,405 & 435 & -1.34 & 2.76 & -6.61 & -3.85 \\
5ac & 374,410 & 484 & -1.19 & 2.58 & -6.58 & -4.00 \\
\hline
\end{tabular}

${ }^{a}$ Calculated using the LUMO level and the optical band gap

ban electron vacuum level of $5.19 \mathrm{~V}$ was considered for the $\mathrm{Fc}^{+} / \mathrm{Fc}$ couple. 


\section{Conclusions}

The synthesis of non-symmetrical fluorinated phenazines has been achieved via nucleophilic aromatic substitution and subsequent acid-promoted electrocyclization and aromatization. The use of decalin as solvent allowed the ortho regioselectivity in the $S_{N} A r$ of anilines on decafluoroazobenzene, affording the desired ortho-substituted azobenzene in satisfactory yields, while dimethyl sulfoxide at room temperature afforded the ortho-substitution products of octafluoroazobenzene in good yields and short reaction times. The orthoanilino substituted azobenzenes prepared were treated with TFA to promote an acid electrocyclic rearrangement to the target non-symmetric fluorinated phenazines in good chemical yields. The tetrafluoro phenazines were analyzed by means of optical and electrochemical properties indicating that the fluorination of the phenazine nucleus strongly influences the electrooptical properties of these heterocycles and makes them interesting systems for photovoltaic and electroluminescent devices. Furthermore, the phenazine LUMO energy levels are higher than that of PCBM $(-3.75 \mathrm{eV})$ thus, they should be interesting acceptor units in bulk heterojunction (BHJ) photovoltaic cells.

\section{Experimental Section}

General. All materials were used as purchased (from Fluorochem Ltd, Tokyo Chemical Industry Co. or SigmaAldrich Chemical Co.). Chromatographic purifications were performed using Merck 9385 silica gel, pore size 60 $\AA ̊$ (230-400 mesh). Melting points were measured with a Stanford Research Systems Optimelt apparatus. IR spectra were recorded with a Perkin Elmer Spectrum 100 FT-IR spectrometer equipped with a universal ATR sampling accessory. ${ }^{1} \mathrm{H},{ }^{13} \mathrm{C}$ and ${ }^{19} \mathrm{~F}$ NMR were recorded with a Bruker AVANCE III HD $400 \mathrm{MHz}$ spectrometer (1H: $400 \mathrm{MHz}, 13 \mathrm{C}: 101 \mathrm{MHz}, 19 \mathrm{~F}: 376 \mathrm{MHz}$ ) Chemical shifts ( $\delta$ ) are expressed in parts per million (ppm), and coupling constants are given in $\mathrm{Hz}$. Splitting patterns are indicated as follows: $s=$ singlet, $d=d o u b l e t, t=$ triplet, $\mathrm{q}=$ quartet, $\mathrm{m}=$ multiplet, $\mathrm{dd}=$ doublet of doublets. Mass analyses were performed using a VG 7070 EQ-HF instrument. Elemental analyses were obtained with an Elementar vario MICRO cube instrument.

General procedure for the synthesis of compounds 4aa, 4ab and 4ac. A mixture of decafluoroazobenzene (2a) $(1 \mathrm{mmol})$, aniline (3a-c) $(1.1 \mathrm{mmol})$ and decalin $(10 \mathrm{~mL})$ was heated at $170{ }^{\circ} \mathrm{C}$ with a $\mathrm{N}_{2}$ flux ended in an aqueous $\mathrm{K}_{2} \mathrm{CO}_{3}$ trap for the time stated in the text. The mixture was then put over a chromatographic column $\left(\mathrm{SiO}_{2}\right)$, elution first with $n$-hexane then with $n$-hexane $/ \mathrm{CH}_{2} \mathrm{Cl}_{2}$ 8:2 afforded the desired compound in a pure form.

(4-methoxyphenyl)\{2,3,4,5-tetrafluoro-6-[(pentafluorophenyl)diazenyl]phenyl\}amine (4aa). Red-violet solid; $\mathrm{mp} 126{ }^{\circ} \mathrm{C} .{ }^{1} \mathrm{H}$ NMR $\left(400 \mathrm{MHz}, \mathrm{CDCl}_{3}\right), \delta(\mathrm{ppm}): 10.75(\mathrm{~s}, 1 \mathrm{H}), 7.02$ (dd, J 8.9, $\left.2.5 \mathrm{~Hz}, 2 \mathrm{H}\right), 6.87(\mathrm{~d}, J 8.9 \mathrm{~Hz}, 2 \mathrm{H})$, $3.81(\mathrm{~s}, 3 \mathrm{H}) .{ }^{19} \mathrm{~F} \mathrm{NMR}\left(376 \mathrm{MHz}, \mathrm{CDCl}_{3}\right), \delta(\mathrm{ppm}):-144.27--144.39(\mathrm{~m}, 1 \mathrm{~F}),-146.71--144.80(\mathrm{~m}, 1 \mathrm{~F}),-148.42$ - -148.49 (m, 1F), -149.91 - -149.98 (m, 2F), -151.61 - -151.70 (m, 1F), -161.82 - -161.99 (m, 2F), -171.64 - 171.70 (m, 1F). IR (ATR): 3171, 2922, 2852, 1647, 1594, 1491, 1432, 1406, 1322, 1267, 1160, 1129, 1079, 1052, 1010, 992, 967, 858, 822, 794, 761, 742, 707, $695 \mathrm{~cm}^{-1}$. Anal. Calcd. for $\mathrm{C}_{19} \mathrm{H}_{8} \mathrm{~F}_{9} \mathrm{~N}_{3} \mathrm{O}: \mathrm{C}, 49.05 ; \mathrm{H}, 1.73 ; \mathrm{N}, 9.03$. Found: C, 49.15; H, 1.70; N, 9.11.

2,3,4,5-tetrafluoro-6-[(pentafluorophenyl)diazenyl]- $\mathrm{N}$-phenylaniline (4ab). Red solid; mp $140{ }^{\circ} \mathrm{C} .{ }^{1} \mathrm{H} \mathrm{NMR}$ (400 MHz, CDCl 3 ), $\delta(p p m): ~ 10.52(s, 1 H), 7.35-7.31(\mathrm{~m}, 2 \mathrm{H}), 7.14(\mathrm{t}, J 7.8 \mathrm{~Hz}, 1 \mathrm{H}), 7.03(\mathrm{dd}, J 7.7,3.1 \mathrm{~Hz}, 2 \mathrm{H})$. ${ }^{19} \mathrm{~F} \mathrm{NMR}\left(376 \mathrm{MHz}, \mathrm{CDCl}_{3}\right), \delta(\mathrm{ppm}):-143.62--143.71(\mathrm{~m}, 1 \mathrm{~F}),-145.26--145.34(\mathrm{~m}, 1 \mathrm{~F}),-145.95--147.10(\mathrm{~m}$, 1F), $-149.15--149.22(m, 2 F),-150.21--151.36(m, 1 F),-160.54--162.26(m, 2 F),-169.11--170.14(m, 1 F)$. 
IR (ATR): 3203, 2922, 2851, 1646, 1593, 1503, 1432, 1405, 1322, 1266, 1162, 1128, 1078, 991, 967, 761,694 $\mathrm{cm}^{-1}$. Anal. Calcd. for $\mathrm{C}_{18} \mathrm{H}_{6} \mathrm{~F}_{9} \mathrm{~N}_{3}$ : $\mathrm{C}, 49.67 ; \mathrm{H}, 1.39 ; \mathrm{N}, 9.65$. Found: $\mathrm{C}, 49.44 ; \mathrm{H}, 1.41 ; \mathrm{N}, 9.85$.

$\mathbf{N}$-(4-Bromophenyl)-2,3,4,5-tetrafluoro-6-[(pentafluorophenyl)diazenyl]aniline (4ac). Red solid; mp $125^{\circ} \mathrm{C}$. ${ }^{1} \mathrm{H}$ NMR (400 MHz, $\left.\mathrm{CDCl}_{3}\right), \delta(\mathrm{ppm}): 10.37(\mathrm{~s}, 1 \mathrm{H}), 7.47-7.40(\mathrm{~m}, 2 \mathrm{H}), 6.88(\mathrm{dd}, J$ 8.7, $3.3 \mathrm{~Hz}, 2 \mathrm{H}) .{ }^{19} \mathrm{~F} \mathrm{NMR}(376$ $\left.\mathrm{MHz}, \mathrm{CDCl}_{3}\right), \delta$ (ppm): -143.09 - -143.21 (m, 1F), -145.17 (ddd, J 19.5, 8.4, 3.9 Hz, 1F), -146.00 (td, J 20.7, 6.6 $\mathrm{Hz}, 1 \mathrm{~F}),-148.99--149.14(\mathrm{~m}, 1 \mathrm{~F}),-150.08$ (t, J $20.9 \mathrm{~Hz}, 1 \mathrm{~F}),-161.09--161.27$ (m, 1F), -168.48 - -168.70 (m, 1F). IR (ATR): 3163, 2958, 2850, 1647, 1588, 1500, 1427, 1404, 1322, 1264, 1242, 1163, 1141, 1072, 1050, $1007,989,971,863,807 \mathrm{~cm}^{-1}$. Anal. Calcd. for $\mathrm{C}_{19} \mathrm{H}_{5} \mathrm{BrF}_{9} \mathrm{~N}_{3}$ : C, 42.05; $\mathrm{H}, 0.98 ; \mathrm{N}, 8.17$. Found: $\mathrm{C}, 42.35 ; \mathrm{H}, 1.03$; N, 8.19.

General procedure for the synthesis of compounds $\mathbf{4 b a}, \mathbf{4 b b}$ and $\mathbf{4 b c}$. Aniline (3a-c) (1.1 mmol) was added to a solution of octafluoroazobenzene $(\mathbf{2 b})(1 \mathrm{mmol})$ and $\mathrm{Et}_{3} \mathrm{~N}(1 \mathrm{mmol})$ in dry DMSO under $\mathrm{N}_{2}$ atmosphere. The mixture was stirred at r.t. for the time stated in the text. An aqueous solution of $\mathrm{KHSO}_{4}$ was then added, the aqueous phase was extracted with $\mathrm{Et}_{2} \mathrm{O}$, the organic layer was dried with $\mathrm{Na}_{2} \mathrm{SO}_{4}$ and the solvent removed under reduced pressure. Chromatography $\left(\mathrm{SiO}_{2}, n\right.$-hexane $\left./ \mathrm{CH}_{2} \mathrm{Cl}_{2} 8: 2\right)$ afforded the desired compound in a pure form.

(4-Methoxyphenyl)\{3,4,6-trifluoro-2-[(2,3,5,6-tetrafluorophenyl)diazenyl]phenyl\}amine (4ba). Violet solid; $\mathrm{mp} 137^{\circ} \mathrm{C} .{ }^{1} \mathrm{H}$ NMR $\left(400 \mathrm{MHz}, \mathrm{CDCl}_{3}\right), \delta(\mathrm{ppm}): 10.52(\mathrm{~s}, 1 \mathrm{H}), 7.08-7.17(\mathrm{~m}, 2 \mathrm{H}), 6.97(\mathrm{dd}, J 8.9,3.0 \mathrm{~Hz}, 2 \mathrm{H})$, 6.85 (dd, J 8.9, $2.8 \mathrm{~Hz}, 2 \mathrm{H}), 3.80(\mathrm{~s}, 3 \mathrm{H}) .{ }^{19} \mathrm{~F} \mathrm{NMR}\left(376 \mathrm{MHz}, \mathrm{CDCl}_{3}\right), \delta(\mathrm{ppm}):-135.49--136.86(\mathrm{~m}, 3 \mathrm{~F}),-142.33$ --144.52 (m, 2F), -150.15 - -152.31 (m, 2F). IR (ATR): 3052, 2961, 2923, 2848, 1738, 1495, 1379, 1256, 1227, $1052,1025,956,868,795,699 \mathrm{~cm}^{-1}$. Anal. Calcd. for $\mathrm{C}_{19} \mathrm{H}_{10} \mathrm{~F}_{7} \mathrm{~N}_{3} \mathrm{O}$ : C, 53.16; $\mathrm{H}, 2.35 ; \mathrm{N}, 9.79$. Found: $\mathrm{C}, 53.06$; H, 2.45; N, 9.69 .

3,4,6-Trifluoro- $\mathrm{N}$-phenyl-2-[(2,3,5,6-tetrafluorophenyl)diazenyl]aniline (4bb). Violet solid; $\mathrm{mp} 106{ }^{\circ} \mathrm{C} .{ }^{1} \mathrm{H}$ NMR $\left(400 \mathrm{MHz}, \mathrm{CDCl}_{3}\right), \delta(\mathrm{ppm}): 10.18(\mathrm{~s}, 1 \mathrm{H}), 7.29(\mathrm{t}, J 8.9 \mathrm{~Hz}, 2 \mathrm{H}), 7.12-7.20(\mathrm{~m}, 2 \mathrm{H}), 7.07(\mathrm{t}, J 8.9 \mathrm{~Hz}, 1 \mathrm{H}), 6.98$ (dd, J 8.9, 3.2 Hz, 2H). $\left.{ }^{19} \mathrm{~F} \mathrm{NMR} \mathrm{(376} \mathrm{MHz,} \mathrm{CDCl} 3\right), \delta(p p m):-137.93--138.46(\mathrm{~m}, 3 \mathrm{~F}),-145.49--146.81(\mathrm{~m}, 2 \mathrm{~F})$, -149.52 - -150.10 (m, 2F). IR (ATR): 3065, 2922, 1591, 1498, 1427, 1379, 1278, 1258, 1176, 1050, 953, 854, 799, 745, $693 \mathrm{~cm}^{-1}$. Anal. Calcd. for $\mathrm{C}_{18} \mathrm{H}_{8} \mathrm{~F}_{7} \mathrm{~N}_{3}$ : C, 54.15; H, 2.02; N,10.52. Found: C, 54.25; H, 2.15; N, 10.44.

$\boldsymbol{N}$-(4-Bromophenyl)-3,4,6-trifluoro-2-[(2,3,5,6-tetrafluorophenyl)diazenyl]aniline (4bc). Violet solid; $\mathrm{mp} 91$ ${ }^{\circ} \mathrm{C} .{ }^{1} \mathrm{H}$ NMR $\left(400 \mathrm{MHz}, \mathrm{CDCl}_{3}\right), \delta(\mathrm{ppm}): 10.03(\mathrm{~s}, 1 \mathrm{H}), 7.42-7.36(\mathrm{~m}, 1 \mathrm{H}), 7.29-7.12(\mathrm{~m}, 4 \mathrm{H}), 6.86-6.80(\mathrm{~m}$, 1H). ${ }^{19} \mathrm{~F}$ NMR (376 MHz, CDCl3), $\delta$ (ppm); -137.96 - -138.16 (m, 3F), -149.53 - -150.03 (m, 4F). IR (ATR): 3163, 2958-2850, 1647, 1588, 1500, 1427, 1404, 1322, 1264, 1242, 1163, 1141, 1072, 1050, 1007, 989, 971, 863, 807 $\mathrm{cm}^{-1}$. Anal. Calcd. for $\mathrm{C}_{18} \mathrm{H}_{7} \mathrm{BrF}_{7} \mathrm{~N}_{3}: \mathrm{C}, 45.21 ; \mathrm{H}, 1.48 ; \mathrm{N}, 8.79$. Found: $\mathrm{C}, 45.35 ; \mathrm{H}, 1.33 ; \mathrm{N}, 8.77$.

General procedure for the synthesis of phenazines 5 . A solution of compound 4 ( $0.5 \mathrm{mmol})$ in TFA (5mL) was stirred at r.t. for $12 \mathrm{~h}$, under $\mathrm{N}_{2}$ atmosphere. The solution was dropped into a saturated aqueous $\mathrm{NaHCO}_{3}$ solution, the resulting aqueous phase was extracted with $\mathrm{CH}_{2} \mathrm{Cl}_{2}$, the organic layer was dried with $\mathrm{Na}_{2} \mathrm{SO}_{4}$ and the solvent removed under reduced pressure. Chromatography $\left(\mathrm{SiO}_{2}, n\right.$-hexane $\left./ \mathrm{CH}_{2} \mathrm{Cl}_{2} 1: 1\right)$ afforded the desired phenazine in a pure form.

1,2,3,4-Tetrafluoro-7-methoxyphenazine (5aa). Yellow solid; mp $180{ }^{\circ} \mathrm{C} .{ }^{1} \mathrm{H} \mathrm{NMR}\left(400 \mathrm{MHz}, \mathrm{CDCl}_{3}\right), \delta: 8.18(\mathrm{~d}$, J $9.5 \mathrm{~Hz}, 1 \mathrm{H}$ ), 7.61 (dd, J 9.5, $2.7 \mathrm{~Hz}, 1 \mathrm{H}), 7.49$ (d, J $2.7 \mathrm{~Hz}, 1 \mathrm{H}), 4.05$ (s, 3H). $\left.{ }^{13} \mathrm{C} \mathrm{NMR} \mathrm{(101} \mathrm{MHz,} \mathrm{CDCl} 3\right) \delta 162.8$ (s), $145.1(\mathrm{~s}), 142.6-140.7(\mathrm{~m}), 139.9-138.5(\mathrm{~m}), 131.1-130.8(\mathrm{~m}), 130.7(\mathrm{~s}), 129.3-129.0(\mathrm{~m}), 128.5(\mathrm{~s})$, 104.5 (s), 56.2 (s). ${ }^{19} \mathrm{~F} \mathrm{NMR} \mathrm{(376} \mathrm{MHz,} \mathrm{CDCl} 3$ ) $\delta-151.61--151.72(\mathrm{~m}, 1 \mathrm{~F}),-152.21--152.32(\mathrm{~m}, 1 \mathrm{~F}),-153.28--$ $153.40(\mathrm{~m}, 1 \mathrm{~F}),-154.00--154.13$ (m, 1F). IR (ATR): 2962, 1675, 1619, 1531, 1486, 1455, 1413, 1374, 1336, $1249,1224,1189,1128,1017,831 \mathrm{~cm}^{-1}$. Anal. Calcd. for $\mathrm{C}_{13} \mathrm{H}_{6} \mathrm{~F}_{4} \mathrm{~N}_{2} \mathrm{O}: \mathrm{C}, 55.33 ; \mathrm{H}, 2.14 ; \mathrm{N}, 9.93$. Found: C, $55.45 ; \mathrm{H}, 2.23 ; \mathrm{N}, 9.91$. 
1,2,3,4-Tetrafluorophenazine (5ab). ${ }^{24}$ Yellow solid; mp $232{ }^{\circ} \mathrm{C} .{ }^{1} \mathrm{H} \mathrm{NMR}\left(400 \mathrm{MHz}, \mathrm{CDCl}_{3}\right), \delta$ (ppm): $8.38-8.32$ $(\mathrm{m}, 2 \mathrm{H}), 8.00-7.93(\mathrm{~m}, 2 \mathrm{H}) .{ }^{13} \mathrm{C}$ NMR (101 MHz, $\left.\mathrm{CDCl}_{3}\right), \delta: 143.2(\mathrm{~s}), 142.5-142.0(\mathrm{~m}), 139.8-139.4(\mathrm{~m})$, $132.4(\mathrm{~s}), 131.2-131.0(\mathrm{~m}), 129.7(\mathrm{~s}) .{ }^{19} \mathrm{~F} \mathrm{NMR}$ (376 MHz, CDCl3), $\delta(\mathrm{ppm}):-151.01--151.08$ (m, 2F), -151.78 --151.84 (m, 2F). IR (ATR): 3096, 3005, 1679, 1594, 1533, 1477, 1389, 1330, 1204, 1140, 1020, $770 \mathrm{~cm}^{-1}$. Anal. Calcd. for $\mathrm{C}_{12} \mathrm{H}_{4} \mathrm{~F}_{4} \mathrm{~N}_{2}$ : C, 57.16; $\mathrm{H}, 1.60 ; \mathrm{N}, 11.11$. Found: $\mathrm{C}, 57.15 ; \mathrm{H}, 1.81 ; \mathrm{N}, 11.33$.

7-Bromo-1,2,3,4-tetrafluorophenazine (5ac). Yellow solid, mp $191{ }^{\circ} \mathrm{C} .{ }^{1} \mathrm{H} \mathrm{NMR}\left(400 \mathrm{MHz}, \mathrm{CDCl}_{3}\right), \delta: 8.54(\mathrm{~d}, J$ $2.1 \mathrm{~Hz}, 1 \mathrm{H}), 8.20$ (d, J $9.3 \mathrm{~Hz}, 1 \mathrm{H}), 8.00$ (dd, J 9.3, $2.1 \mathrm{~Hz}, 1 \mathrm{H}) .{ }^{13} \mathrm{C} \mathrm{NMR}\left(101 \mathrm{MHz}, \mathrm{CDCl}_{3}\right), \delta 143.3(\mathrm{~s}), 142.9-$ $142.0(\mathrm{~m}), 141.8(\mathrm{~s}), 140.4-139.4(\mathrm{~m}), 136.2(\mathrm{~s}), 131.7(\mathrm{~s}), 131.5-131.3(\mathrm{~m}), 131.2-130.9(\mathrm{~m}), 130.8(\mathrm{~s})$, 127.4 (s). ${ }^{19} \mathrm{~F} \mathrm{NMR}\left(376 \mathrm{MHz}, \mathrm{CDCl}_{3}\right.$ ), $\delta:-149.51$ - -149.66 (m, 1F), -150.05 - -150.18 (m, 1F), -151.27 - -151.38 (m, 2F). IR (ATR): 3067, 1676, 1596, 1532, 1480, 1443, 1368, 1330, 1016, 933, $829 \mathrm{~cm}^{-1}$. Anal. Calcd. for $\mathrm{C}_{12} \mathrm{H}_{3} \mathrm{BrF}_{4} \mathrm{~N}_{2}$ : C, 43.54; $\mathrm{H}, 0.91 ; \mathrm{N}, 8.46$. Found: $\mathrm{C}, 43.48 ; \mathrm{H}, 0.88 ; \mathrm{N}, 8.45$.

1,2,4-Trifluoro-7-methoxyphenazine (5ba). Yellow solid; mp $\left.229{ }^{\circ} \mathrm{C} .{ }^{1} \mathrm{H} \mathrm{NMR} \mathrm{(400} \mathrm{MHz,} \mathrm{CDCl}^{3}\right), \delta(\mathrm{ppm}): 8.17$ (d, J $9.5 \mathrm{~Hz}, 1 \mathrm{H}), 7.57$ (dd, J 9.5, $2.7 \mathrm{~Hz}, 1 \mathrm{H}), 7.50(\mathrm{~d}, J 2.7 \mathrm{~Hz}, 1 \mathrm{H}), 7.36-7.41(\mathrm{~m}, 1 \mathrm{H}), 4.05(\mathrm{~s}, 3 \mathrm{H}) .{ }^{13} \mathrm{C} \mathrm{NMR}(101$ $\mathrm{MHz}, \mathrm{CDCl} 3) \delta(\mathrm{ppm}): 163.1$ (s), 153.3 (ddd, J 262.4, 12.0, 4.5 Hz), 147.9 (dt, J 254.0, $12.3 \mathrm{~Hz}$ ), 145.6 (s), 140.1 (t, J $2.4 \mathrm{~Hz}$ ), 139.8 (ddd, J 256.8, 12.9, 6.2 Hz), 134.7 (dd, J 10.5, 6.2 Hz), 131.1 (s), 129.9 (d, J 14.3 Hz), 128.0 (s), $104.4(\mathrm{~s}), 104.6$ - $103.9(\mathrm{~m}), 56.2$ (s). ${ }^{19} \mathrm{~F}$ NMR (376 MHz, CDCl $) \delta(\mathrm{ppm}):-124.57--124.70(\mathrm{~m}, 1 \mathrm{~F}),-131.29$ (dd,.J.16.7, 2.4 Hz, 1F), -155.65 - -155.82 (m, 1F). IR (ATR): 3040, 2976, 1653, 1620, 1500, 1457, 1422, 1369, $1309,1251,1266,1171,1127,1100,1014,993,951,867,847,756,725 \mathrm{~cm}^{-1}$. Anal. Calcd. for $\mathrm{C}_{13} \mathrm{H}_{7} \mathrm{~F}_{3} \mathrm{~N}_{2} \mathrm{O}: \mathrm{C}$, 59.10; H, 2.67; N, 10.60. Found: C, 59.28; H, 2.77; N, 10.48.

1,2,4-Trifluorophenazine (5bb). Yellow solid; mp $231{ }^{\circ} \mathrm{C} .{ }^{1} \mathrm{H} N M R\left(400 \mathrm{MHz}, \mathrm{CDCl}_{3}\right), \delta(\mathrm{ppm}): 8.41-8.29(\mathrm{~m}$, $2 \mathrm{H}), 8.01-7.88(\mathrm{~m}, 2 \mathrm{H}), 7.48$ (ddd, J 10.2, 9.5, $6.3 \mathrm{~Hz}, 1 \mathrm{H}) .{ }^{13} \mathrm{C}$ NMR (101 MHz, CDCl3) $\delta(p p m): 154.8-153.8$ (m), $152.1-151.4(\mathrm{~m}), 147.6$ (dt, J 254.9, $12.1 \mathrm{~Hz}$ ), 143.2 (dd, J 105.1, 2.4 Hz), $141.5-141.0$ (m), $139.0-138.4$ $(\mathrm{m}), 132.7$ (s), 131.8 (s), 131.7 (s), 130.1 (s), 129.6 (s), 105.9 (dd, J 27.3, $24.3 \mathrm{~Hz}) .{ }^{19} \mathrm{~F} \mathrm{NMR}\left(376 \mathrm{MHz} \mathrm{CDCl}_{3}\right), \delta$ (ppm): -123.95 (dd, J 20.6, $2.0 \mathrm{~Hz}, 1 \mathrm{~F}),-130.88$ (d, J $14.4 \mathrm{~Hz}, 1 \mathrm{~F}),-154.42$ (dd, J 20.6, $16.4 \mathrm{~Hz}, 1 \mathrm{~F})$. IR (ATR): 3041, 2922, 2853, 1658, 1614, 1529, 1490, 1467, 1423, 1403, 1385, 1361, 1328, 1318, 1289, 1248, 1218, 1187, 1138, 1100, 989, 972, 908, 864, 834, 784, 764, 730, 700, 656, 643, 605, 596, $582 \mathrm{~cm}^{-1}$. Anal. Calcd. for $\mathrm{C}_{12} \mathrm{H}_{5} \mathrm{~F}_{3} \mathrm{~N}_{2}$ : C, 61.55; $\mathrm{H}, 2.15 ; \mathrm{N}, 11.96$. Found: $\mathrm{C}, 61.50 ; \mathrm{H}, 2.16 ; \mathrm{N}, 11.99$.

7-Bromo-1,2,4-trifluorophenazine (5bc). Yellow solid; mp $182{ }^{\circ} \mathrm{C} .{ }^{1} \mathrm{H} N M R\left(400 \mathrm{MHz}, \mathrm{CDCl}_{3}\right), \delta(\mathrm{ppm}): 8.52$ (d, J $2.0 \mathrm{~Hz}, 1 \mathrm{H}), 8.18(\mathrm{~d}, J 9.3 \mathrm{~Hz}, 1 \mathrm{H}), 7.96$ (dd, J 9.3, $2.1 \mathrm{~Hz}, 1 \mathrm{H}), 7.49$ (ddd, J 10.1, 9.5, $6.3 \mathrm{~Hz}, 1 \mathrm{H}) .{ }^{13} \mathrm{C} \mathrm{NMR}(101$ $\mathrm{MHz}, \mathrm{CDCl} 3$ ), $\delta$ (ppm): 153.1 (ddd, J 264.4, 11.8, $4.7 \mathrm{~Hz}$ ), 148.1 (dt, J 256.2, $12.3 \mathrm{~Hz}$ ), 143.7 (d, J $2.1 \mathrm{~Hz}), 141.2$ (s), 140.0 (ddd, J 19.5, 15.2, $6.5 \mathrm{~Hz}$ ), 135.7 (s), $135.3-135.0(\mathrm{~m}), 131.8-131.6(\mathrm{~m}), 131.6(\mathrm{~d}, J 6.1 \mathrm{~Hz}), 131.1$ (s), 127.7 (s), 106.3 (dd, J 27.4, 24.2 Hz). $\left.{ }^{19} \mathrm{~F} \mathrm{NMR} \mathrm{(376} \mathrm{MHz,} \mathrm{CDCl}\right), \delta(p p m):-123.49$ (d, J 20.8 Hz, 1F), -129.38 (d, J $17.5 \mathrm{~Hz}, 1 \mathrm{~F}$ ), -153.98 (dd, J 20.6, $15.9 \mathrm{~Hz}, 1 \mathrm{~F}$ ). IR (ATR): 3067, 3034, 2922, 2852, 1745, 1652, 1599, 1530, $1484,1452,1419,1364,1316,1277,1240,1207,1173,1140,1100,1049,1027,993,968,922,870,827,805$, 796, 740, 710, 645, 628, $596 \mathrm{~cm}^{-1}$. Anal. Calcd. for $\mathrm{C}_{12} \mathrm{H}_{4} \mathrm{BrF}_{3} \mathrm{~N}_{2}: \mathrm{C}, 46.04 ; \mathrm{H}, 1.29 ; \mathrm{N}$ 8.95. Found: $\mathrm{C}, 46.00 ; \mathrm{H}$, $1.25 ; \mathrm{N}, 8.91$.

\section{Electrochemistry}

Solutions of $\mathbf{5 a a}, \mathbf{5 a b}$, and $\mathbf{5 a c}$ were prepared dissolving the molecules in $0.1 \mathrm{M}$ Tetrabutylammonium perchlorate in 2:1 vol ratio $\mathrm{CH}_{3} \mathrm{CN}: \mathrm{CH}_{2} \mathrm{Cl}_{2}$. The concentration of electroactive species was around $5 \times 10^{-4} \mathrm{M}$. Cyclic Voltammetries (CV) and Differential Pulse Voltammetry (DPV) were carried out at scan rate of $50 \mathrm{mV} \mathrm{s}$ and $20 \mathrm{mV} \mathrm{s}^{-1}$, respectively, using an Eg\&G PARSTAT 2273 potentiostat/galvanostat in a two compartment, three electrode electrochemical cell in a glove box filled with $\operatorname{Ar}\left(\left[\mathrm{O}_{2}\right]\right.$ and $\left[\mathrm{H}_{2} \mathrm{O}\right] \leq 1$ ppm). The working, counter, and the pseudo-reference electrodes were a glassy carbon pin, a Pt flag and an $\mathrm{Ag} / \mathrm{AgCl}$ wire, respectively. The working electrodes discs were well polished with alumina $0.1 \mu \mathrm{m}$ suspension, sonicated for 
$15 \mathrm{~min}$ in deionized water, and then washed with 2-propanol. The $\mathrm{Ag} / \mathrm{AgCl}$ pseudo-reference electrode was calibrated, by adding ferrocene $\left(5 \times 10^{-5} \mathrm{M}\right)$ to the test solution before and after each measurement.

\section{Acknowledgements}

We thank Dr. Giorgio Patriarca for the NMR characterization, Dr. Matteo Tironi for the preparation of one sample and Prof. Giovanni Palmisano (Dipartimento di Scienza e Alta Tecnologia, Università degli Studi dell'Insubria) for his fine suggestions.

\section{Supplementary Material}

CV traces and DPVs of the derivates $\mathbf{5 a a}, \mathbf{5 a b}$, and $\mathbf{5 a b}$ used to calculate the values of table $2 ;{ }^{1} \mathrm{H},{ }^{13} \mathrm{C}$ and ${ }^{19} \mathrm{~F}$ NMR spectra of phenazines $\mathbf{5}$. This material can be found using the link "Supplementary Material" in the journal issue contents page.

\section{References}

1. Laursen, J. B.; Nielsen, J. Chem. Rev. 2004, 104, 1663-1685. https://doi.org/10.1021/cr020473j

2. Conda-Sheridan, M.; Marler, L.; Park, E.-J.; Kondratyuk, T. P.; Jermihov, K.; Mesecar, A. D.; Pezzuto, J. M.; Asolkar, R. N.; Fenical, W.; Cushman, M. J. Med. Chem. 2010, 53, 8688-8699. https://doi.org/10.1021/jm1011066

3. Luo, Q.; Hu, H.; Peng, H.; Zhang, X.; Wang, W. Chin. J. Chem Eng. 2015, 23, 699-703. https://doi.org/10.1016/j.cjche.2015.01.001

4. Garrison, A. T.; Abouelhassan, Y.; Kallifidas, D.; Bai, F.; Ukhanova, M.; Mai, V.; Jin, S.; Luesch, H.; Huigens, R. W. III Angew. Chem., Int. Ed. 2015, 54, 14819-14823. https://doi.org/10.1002/anie.201508155

5. Schwaben, J.; Mìnster, N.; Klues, M.; Breuer, T.; Hofmann, P.; Harms, K.; Witte, G.; Koert , U. Chem. Eur. J. 2015, 21, 13758-13771.

https://doi.org/10.1002/chem.201501399

6. Yamamoto, T.; Okuda, T. J. Electroanal. Chem. 1999, 460, 242-244. https://doi.org/10.1016/S0022-0728(98)00322-2

7. Papagni, A.; Facchetti, A.; Zhihua, C. U.S. Pat. Appl. Publ., US 20160351815 A1 20161201, 2016.

8. Matsui, M; Ikeda, R.; Kubota, Y.; Funabiki, K. Tetrahedron Lett. 2009, 50, 5047-5049. https://doi.org/10.1016/j.tetlet.2009.06.095

9. Kitamura, T.; Fudemoto, H.; Wada, Y.; Murakoshi, K.; Kusaba, M.; Nakashima, N.; Majima, T.; Yanagida, S. J. Chem. Soc. Faraday Trans. 1997, 93(2), 221-229. https://doi.org/10.1039/a604920f

10. Sawhney, S. N.; Boykin, D. J. Heterocycl. Chem. 1979, 16, 397-400. https://doi.org/10.1002/ihet.5570160243 
11. Seth, K.; Roy, S. R.; Chakraborti, A. K. Chem. Commun. 2016, 52, 922-925. https://doi.org/10.1039/C5CC08640J

12. Yu, L.; Zhou, X.; Wu, D.; Xiang, H. J. Organomet. Chem. 2012, 705, 75-78. https://doi.org/10.1016/i.jorganchem.2011.12.030

13. Wohl, A.; Aue, W. Chem. Ber. 1901, 34, 2442-2450. https://doi.org/10.1002/cber.190103402183

14. Maffei, S.; Pietra, S.; Cattaneo, A. Gazz. Chim. Ital. 1953, 83, 327-334.

15. Challand, S. R.; Herbert, R. B.; Hollim, F. G. Chem. Commun. J. Chem. Soc. D 1970, 1423-1425.

16. Emoto, T.; Kubosaki, N.; Yamagiwa, Y.; Kamikawa, T. Tetrahedron Lett. 2000, 41, 355-358. https://doi.org/10.1016/S0040-4039(99)02061-4

17. Garrison, A. T.; Abouelhassan, Y.; Kallifidas, D.; Tan, H.; Kim, Y. S.; Jin, S.; Luesch, H.; Huigens, R. W., III J. Med. Chem. 2018, 61, 3962-3983.

https://doi.org/10.1021/acs.jmedchem.7b01903

18. Sirrey, A. R. Org. Synth. 1946, 26, 86-90. https://doi.org/10.15227/orgsyn.026.0086

19. Lian, Y.; Hummel, J. R.; Bergman, R. G.; Ellman, J. A. J. Am. Chem. Soc. 2013, 135, 12548-12551. https://doi.org/10.1021/ja406131a

20. Birchall, J. M.; Haszeldine, R. N.; Kemp, J. E. G. J. Chem. Soc. C 1970, 3, 449-455. https://doi.org/10.1039/i39700000449

21. Hudson, A. G.; Pedler, A. E.; Tatlow, J. C. Tetrahedron Lett. 1968, 2143-2146. https://doi.org/10.1016/S0040-4039(00)89762-2

22. Lee, D.-C.; Cao, B.; Jang, K.; Forster, P. J. Mater. Chem. 2010, 20, 867-873. https://doi.org/10.1039/B917601B

23. Scriven, E. F. V.; Suschitzky, H.; Garner, G. V. Tetrahedron Letters 1973, 14, 103-106. https://doi.org/10.1016/S0040-4039(01)95588-1

24. Shteingarts, V. D.; Budnik, A. G. Izvestia Sib. Division AN SSSR, ser.khim. (russ) 1967, 3, p. $124-127$.

25. Del Buttero, P.; Gironda, R.; Moret, M.; Papagni, A.; Parravicini, M.; Rizzato, S.; Miozzo, L. Eur. J. Org. Chem. 2011, 2265-2271.

https://doi.org/10.1002/ejoc.201001647

26. Jansen, W. B. Chem. Rev. 1978, 78, 1-22. https://doi.org/10.1021/cr60311a002

27. Coghi, P.; Papagni, A.; Po', R.; Calabrese, A.; Tacca, A.; Savoini, A.; Stuknyte, M. New J. Chem. 2015, 39, 3615-3623.

https://doi.org/10.1039/C4NJ02359E

28. Hamon, F.; Djedaini-Pilard, F.; Barbot, F.; Len, C. Tetrahedron 2009, 65, 10105-10123. https://doi.org/10.1016/i.tet.2009.08.063

29. Andreosso, I.; Papagni, A.; Vaghi, L. J. Fluorine Chem. 2018, 216, 124-127. https://doi.org/10.1016/j.jfluchem.2018.10.012

30. Vaghi, L.; Sanzone, A.; Sassi, M.; Pagani, S.; Papagni, A.; Beverina, L. Synthesis 2018, 50, 1621-1628. https://doi.org/10.1055/s-0036-1591937

31. Sawyer D. T.; Komai, R. Y. Anal. Chem. 1972, 44, 715-721. https://doi.org/10.1021/ac60312a002 